\title{
Burying as part of life in the European context
}

FROLÍKOVÁ PALLÁNOVÁ Klára ${ }^{1, a^{*}}$, KOVÁŘ Jan ${ }^{2, b}$, DLÁBIKOVÁ Ivona ${ }^{3, c}$, PROSKEOVÁ Eva ${ }^{4, ~ d, ~ T O M E C ̌ K O V A ́ ~ Z ̇ u z a n a ~}{ }^{5, \text { e }}$

\author{
1, 2, 3, 4. 5VŠB-TUO, FAST, L. Podéště 1875/17, 70833 Ostrava - Poruba, Czech Republic \\ aklara.frolikova@vsb.cz, bjkatelier@opava.cz, 'ivona.dlabikova.st@vsb.cz, \\ deva.proskeova@seznam.cz, e zuztomeckova@gmail.com
}

Keywords: Funeral, burying, cemeteries, cremation, interment.

\begin{abstract}
One of the eternal influencing factors on the development of people's place of living is the problem of burying. These problems change in time but consequentially require long-term planning, the reservation of an area in a proper territorial community with all planned consequences thoroughly thought through. Cemeteries come close to the course of life in society and its relationship to the values of previous generations. According to the state of the cemetery and its tidiness it is possible to make a judgement on the cultural advancement of society. The loss of rituals and the encroaching secularization of society are connected to making the problems of burials and burying taboo. The objective of this work is an attempt to change this state by leading a discussion on the tradition of burying as part of life in the European context of selected cemeteries in Vienna, Brno and Prague. There are taken into consideration the historical influences and the reasons of introducing legal arrangements, historical connections, urban establishments, funereal arts, architecture and pictures of the cemeteries that were studied. There are observed the present trends in burying and the arrangement of existing cemeteries and comparing them with interEuropean influences. The problems of cemeteries are presented with their projection into the future on the cultural and ethical level of the moral code.
\end{abstract}

\section{Introduction}

A visible manifestation of going through mourning is the building of cemeteries. Cemeteries provide a place of reverence for the collective memory of society in remembrance of the past. They are parts of a historical and cultural heritage. The spiritual value of graves is connected to the person who in buried in it and through its importance to society. Between the years $2004-2006$ there were registered 5799 non-disturbed public and non-public burial sites. 1565 of these cemeteries, which is $33 \%$ [1] pg. 165, are in possession of the church. A public burial site is thought of as a place for burying all deceased without difference. A non-public then is a cemetery or a row of vaults or church graves. According to Roman law care about the burial site of public things, but purely private matters, respectively the moral responsibilities of the bereaved persons ... with the coming of Christianity ... becomes the subject of care of all members of the religious community [1] pg. 29.

Visiting a cemetery today is mostly the subject of interest of the bereaved. It serves as a reminder, a way of coming to terms with the mourning, the possibility to be with one's closest, and it is also a common duty to take care of the grave during times of important holidays.

No society can do without burying, and at the same time each civilization makes distinctions according to concerns about the dead. In cemeteries various architectural styles, layout classifications and areas of greenery pervade. Cemeteries are witnesses to various time epochs and styles, that is they are preservers of time.

The forms of burial differ in various parts in the world, generally however interment (the placing of the dead into the ground) and cremation (the cremating of the dead) dominate. A third less common form is leaving the body for scientific purposes. 
Secularization of society leads to the loss of funerals and weddings $(60 \%$ of funerals are without ceremony). Without ceremony, the bereaved are deprived of lamentation, which eases the soul and shifts mourning into another phase.

For almost two millennia death was perceived as "tamed" ...death close and intimately known, but also presently weakened and unharming...in ...dispute with our feelings - death defames us with such a threat that we are afraid to express its name...today death has gone wild and it used not to have been that way. The most ancient death was tamed [2] pgs. 43-44.

It proposes such a question on where the development of cemeteries should be directed further in order for it to become a part of everyday life, and in the same way death, which has been made taboo and is denied. If it is possible to create an ecosystem enriching the environment at a time of the technical advancement of nations and industry, congesting individual cities and acting on the environment. If it is possible to return to our origin, to nature and blend with it to reach a state of peace. To classify these oases into existing sites and to create a place for life - that is, for the everyday or occasional enjoyment of the living, in respect and in remembrance of the deceased.

\section{History. The History of Burying and Legislation Affecting Burying in the Areas of the Czech Lands.}

The first funerals took place in marshes and in crags. This later led covering with stones and gradually placement into graves and cremation. The beginnings of cemeteries are connected to the settlement of tribes and through changes in the nomadic way of life.

At the time of Great Moravia, we perceive three nations, three approaches to burying in our areas. Dead Celts were buried with things, which accompanied them during their lives. They were buried by interment, and sporadically cremation appeared. The Romans enacted burying in ten of twenty legal records (5th C BCE). They write not to bury or burn a dead person in a city ... women neither to lacerate their faces nor lament at a funeral...nor give gold...[1] pgs. 22-23. They used interment and cremation. Slavic tribes then used cremation and placement in ceramic vessels.

The first row of graves were placed outside a settled area (by roads and similar places), with the coming of Christianity they were shifted closer to a settlement or became part of it (in the vicinity of a church, in a church). In the second millennia interment significantly dominated (as a legacy of preChristian cultures and Christianity). Lex Salica from the years $507-11$ states the right of each person to a burial place, without the possibility of having the place occupied by younger graves.

In the year 581 the prohibition to place one body on another ended in Mácon. The Carolingian Code of Law Capitulatio de partibus Saxoniae prohibited burial under "pagan" burial mounds and required the placing of a body in church cemeteries.

In the year 789 Charlemagne issued a decree, which prohibited cremation under punishment of death. This prohibition was respected in Europe for more than a thousand years.

Since the 11th century it has led to a shift from burying in adjacent areas to the centre of events in our lands. Since the twelfth century there has been recorded an increase in country churches with cemeteries. So cemeteries became common parts of towns and villages. They were accessible places for the public, amply visited and they served as a town square [3] pg. 226.

In the year 1594 Professor Felix Platter in Basil began to use the bodies of the dead for autopsies. In Bohemia the first autopsy was done by Professor Jan Jesenský at Rejček College on 12.6.1600.

In the year 1782, Joseph II reformed funeral services by the Dvorský Decree. Among the most significant orders, which considerably influenced the development and planning of our towns and municipalities was the establishment of cemeteries outside town centers. After eight centuries this led to the exclusion of the dead from the life of the community. From that also came a mandatory enclosure with a cemetery wall and the recommendation to separate a cemetery from the town by a forest, hill or river [1] pg. 171.

Up until the year 1955 our cemeteries were completely under the power of the church. 
The development of a cremation movement became an issue of the second half of the 19th century and it is in connection to the development of big cities. Cremation was first legalized in Italy in the year 1874, and the first crematorium was built in Milan in the year 1876. The first cremation facility in the Austro-Hungarian Empire was built in the year 1917 in Liberec [2]. Since cremation by fire was prohibited in the monarchy, this activity had to be postponed until the foundation of an independent Czechoslovakia. So in the year 1919 a funeral using cremation was enacted through the law Lex Kvapil. In the first half of the twentieth century the Catholic Church still strictly prohibited cremation up until the Second Vatican Council (1962 -65), since when there was introduced the doctrine that burial into the ground was praiseworthy, but cremation could also be a possibility. According to the Law ( $\$ 9$ Declaration No. 8/1955) cremated remains should be placed in burial grounds. This was made looser with the issuance of a new law about funeral practices (No. 256/2001). It has not already been determined where cremated human remains should be placed. Another important valid law is Law 122/2004 of the Collection of Laws about wartime graves and places of reverence.

In the year 2008, under the auspices of the Ministry of Local Development of the Czech Republic standards were created for the work of gravediggers and the qualifications for gravediggers and tomb builders were officially established, finishing up with an appropriate exam.

Since the 1990s, there began the formation in Great Britain of natural cemeteries, as a return to the original natural ways of doing burials. This trend has spread to Germany, the Netherlands, Sweden, North America, Australia and Japan. In our country it comes across the strict geometry of burial grounds. They are hemmed in and subjected to rules for graves and tombs, in the same way as in the consequent location of cemeteries given by the heritage of the monarchy. So it was made looser only for dispersing and dumping meadows, where the absence of the name of the deceased speeds up the departure of the deceased from this world.

\section{The Present Time. Current forms of burying in the Czech Republic.}

Up to now in our country burying has remained a long-term tradition. This mostly deals with the placing of the body of the deceased into a coffin and placing it into the ground or a tomb. Cremation and the resultant placing of an urn with the cremated body into the ground or into a proper display case on the surface of the tomb in an urn grove or into the alcove of a columbarium, was placed on the same level as burials into the ground after the year 1955. There was gradually added the scattering of ashes on scattering meadows and dumping on dumping meadows. Cremation totally dominates today ( $80 \%$ of the total number of funerals in the Czech Republic). There cannot be supposed any more radical development in another direction, because the Czech Republic presently occupies third place in worldwide ranking in the number of crematoriums per inhabitant [4] pg. 98. This change should have an influence on the arrangement and planning of cemeteries.

Cemeteries in the Czech Republic are mostly marked out by a regular network of streets and lanes with a dense linear arrangement of graves. The street at the main entrance used to be lined with the graves of important persons (another possibility is a circle of honor, the corner of streets, and similar arrangements). For example, a circle of honor with the gravestones of famous artists is in the Central Cemetery in Brno. Graves, as forms of an after-death "dwelling forever", urge considerations about the size and crampedness of "dwellings". Graves are crowned with artistic works, where there are individual icons, packed in next to each other, competing together.

Streets, lined of grown trees and low bushes, usually cover the rear parts of gravestones. A grave or tomb is sometimes supplemented with a bush or tree, which grows from the body of a person. It is however necessary to keep in respect that greenery has an accompanying aesthetic effort and the area of a cemetery or burial ground mostly is not an area with public greenery [4]. Old cemeteries are marked out by high biodiversity, which used to be for reverential peace through the significant nesting sites for birds. 
In the ideal case, streets and lanes are supplemented by benches, waste bins, a water distribution system, and other facilities. Sometimes it is supplemented by a bench by the grave, where a person can sit and visit with their closest. A frequent phenomenon is a bird house - the presence of life.

Flowers in flowerpots, which the bereaved must regularly take care of, in the same way as their closest during life. In the same way there are graves covered with ivy, losing their identity, or memorials to those fallen facing the grave. Locations of raised graves and tombs and steps built to them, where we go up higher to visit the deceased. There are usually dispersing and dumping meadows, whose periphery is lined with planted flowers, for freeing up the tight linear arrangement of graves, The anonymous location of the last resting place is supplemented by common flowerpots planted with flowers as paying attention to the deceased - a mutual sharing in a common fate (death). An urn covered in the ground under a stone slab, a urn in a columbarium, a urn fitted with a canopy or stone sarcophagus. Shelters for urns do not remain under the open sky. A cemetery lined with walls, sometimes a fence, separated from the world of the living. Cemeteries developing, cemeteries grown together, sometimes also divided, parts of them disturbed, withdrawing from the development of the town, and sometime totally disturbed, replaced by a park, by a construction and sometimes only a rubble site. Cemeteries with specific memorials (for example, The Central Cemetery in Brno, Olšany Cemetery) in Brno - Židenice, nowhere coming to an end, unenclosed. Long lines of streets lead to the peak of the slope itself and below the slope of the road, behind the road in a newly restricted field. The New Cemetery in Prague in D́áblice, with a network of organically lead streets, with an attempt to open up areas, but disciplined by the strict outlines of Honorary Burial Sites.

\section{The Future. Influences from abroad.}

By directing the further development of cemeteries in our country it is possible to consider some examples from abroad, but also the several few previous and present designs in the Czech Republic.

In Great Britain there began to establish the first environmentally-friendly burial sites and natural cemeteries in the 1990s (the first was founded in the year 1994). The basic principle is harmony with nature. Cemeteries have the form of forests, meadows and parks. The flora and fauna have to be typical for a given area. In some natural cemeteries ash is placed towards the roots of grown trees, otherwise a tree is planted on each grave and till a "memorial forest" is established. Sheep graze in meadow cemeteries. Harmony with nature requires leaving minimal environmental traces. So the dead join into a cycle with nature. Natural, easily degradable materials are used. Gravestones are not used. Minute wooden signs are used. Protected reserves have been founded, on which original species of plants and animals do well. A pleasant place for life has been established, a place urging visits and not forcing death away.

In the Czech Republic a natural cemetery was founded in Dáblice in the unused part of the cemetery, where ashes will be placed towards the roots of existing trees and a Forest of Remembrance will be founded (in autumn 2014). The idea "beautiful death" is reflected in wooded cemeteries (called forest cemeteries), which are environmentally friendly burial grounds, but coming close to the idea of natural cemeteries (the most well-known in Zlín since 1930 and in Hradec Králové). A singular method of construction is presented by the conception of the Central Cemetery in Vienna. The cemetery is built for the travel road network, which corresponds to the extent of the locality. There is a possible entry by bus or the use of bus lines in the area of the cemetery. From the main gate there leads a road to the dominant cemetery church from a wellknown representative of the Jugendstil Max Hegel. The main entry and surroundings of the church is spread out into arcades with the tombs of well-known people. So in the same way a street connecting into two points is lined with graves of honor. Other graves line a slightly raised field established by regular, geometric divisions of the cemetery area. The increase creates a distance from the graves or tombs from the accessible road network. The graves are arranged around a periphery of loose parts, where high grass waves, or a poorly arranged forest grows up and so it 
leaves the graves on the edge of the road "to subside". Ing. Paclová states that in the west, north and south we meet with a greater moderation in the area of the cemetery than how it is here. A unified area of greenery mostly covers it from which only a memorial or cross sticks out... a place of reverence then acts with a calming, smoothing impression... conversely Central European areas originally presented graves full of flowers... Our design imitates the cemeteries in central Austria, ....4] 128-129 which is confirmed by surveys of Vienesse cemeteries (above). Some visitors perceive dense, linearly arranged graves by the laying-out of entire tombs for a ,morbid“" appearance, which discourages from visiting the place. The individual style of arranging graves however corresponds to the character and style of each tenant in the same way as current residential buildings. In simplifying (gradually, or radically) the entire look of a cemetery it is in such a way possible to achieve the positive perception of visitors so necessary for cleansing their souls.

\section{Summary}

In Czech society the older and dying are being displaced, and they are not in a favorable position in society. Children do not have contact with the dying and the deceased. The missing funeral rituals today are the basis for the future problems of those left behind. The result is the inability of society to deal with the death of one's closest, one's own. There is a vested role also played by cremation, which brings the possibility for placement in scattering or dumping meadows and therefore indirectly supports the development of funerals without ceremonies.

The basic problem with making death taboo and forcing it out from everyday life is possible to observe from the reforms of Maria Teresa mostly Joseph II, when cemeteries were centralized and shifted 15 minutes walk from the border of a community.

In regards to the development of the community, today these cemeteries are mostly again part of the urban area. It is necessary to move their significance farther, to not act as a strictly hemmed in area, which is bypassed and limits accessibility to the surroundings. It is again necessary to sort them into the structure of towns and villages.

According to the available information there is offered a way of simplification, a park layout, a natural appearance as a display of our origin in nature. A harmonic, calming environment, awakening respect towards the deceased and the bereaved, towards nature, towards its cycles and the inevitable end of all life - with respect towards death without prejudice and huge apprehension.

The creation of these public facilities must increase the cultural level of ceremonies, which are very personal in the lives of individuals, and are presently supporting the concerns of communities for each citizen. They are central parts of towns. They have to be presented through town-planning and architecture positively acting as a prerequisite for finding new ideas so that they can add to future generations.

This work was supported by means of the V̌̌B-TUO Student Grant Competition. Project registration number is SP2014/152.

\section{References}

[1] T. Kotrlý, Pohřebnictví, Právní zajištění piety a důstojnosti lidských pozůstatků a ostatků, first ed., Linde, Praha, 2013, 308 p.

[2] P. Ariès, Dějiny smrti, Ardo, Praha, 2000, 358 p.

[3] O. Nešporová, O smrti a pohřbívání, Centrum pro studium demokracie a kultury, first ed., Brno, 2013, 351 p.

[4] D. Stejskal, D. Šejvl a kol., Pohřbívání a hřbitovy, first ed., Wolters Kluwer ČR, a.s., Praha, 2011, 464 p. 